\title{
Effects of imidacloprid on Harmonia axyridis (Coleoptera: Coccinellidae) larval biology and locomotory behavior
}

\author{
CharLes VINCENT ${ }^{1}$, ANDRÉ FERRAN ${ }^{2}$, LUDOVIC GUIGE ${ }^{2}$, JACQues GAMBIER ${ }^{2}$ and JACQues BRUN ${ }^{3}$ \\ ${ }^{1}$ Centre de Recherche et de Développement en Horticulture, Agriculture et Agro-Alimentaire Canada, 430 Boul. Gouin, \\ Saint-Jean-sur-Richelieu, QC Canada J3B 3E6; e-mail: vincentch@em.agr.ca \\ ${ }^{2}$ INRA-Laboratoire de Biologie des Invertébrés, 37 boul. du Cap, 06600 Antibes, France \\ ${ }^{3}$ INRA-Laboratoire de Biologie des Invertébrés, 1382 Route de Biot, 06560 Valbonne, France
}

Key words. Harmonia axyridis, Coccinellidae, imidacloprid, locomotory behavior, $\mathrm{LD}_{50}$, sub-lethal effects.

\begin{abstract}
The effects of imidacloprid on 1-day-old third instars of Harmonia axyridis were assessed by topical treatment and contact with treated glass plates in laboratory bioassays. When $5 \mu \mathrm{l}$ of imidacloprid solutions were applied topically, the $\mathrm{LD}_{50} \mathrm{was} 0.085 \mathrm{~g} / \mathrm{l}$ per insect after $24 \mathrm{~h}$. Contact with imidacloprid-treated plates had little effect on the number of third instars that became adults. Average duration of larval development was not significantly affected by duration of contact and imidacloprid concentrations. There were no significant differences in maximal larval weight, weight gain and day at maximum larval weight. There were significant differences in average weight gain per day (from third instar to prepupa) after treatments with different imidacloprid concentrations. A temporary knockdown effect was observed with higher concentrations and longer durations of contact with treated plates. Compared with untreated third instars, contact with imidacloprid-treated plates caused an increase in time spent (in seconds) on the glass plates resulting from an increase in number of stops (per second) and angular speed (degrees per second) and a decrease in linear speed, excluding stops ( $\mathrm{mm} / \mathrm{second})$. The changes in locomotory behavior (i.e., duration of stay on untreated plate, number of stops and angular speed) lasted up to $24 \mathrm{~h}$ after contact with imidacloprid-treated plates.
\end{abstract}

\section{INTRODUCTION}

While searching for prey, coccinellid predators show complex changes in behavior (Ferran \& Dixon, 1993). They exhibit extensive searchs (relatively fast and linear movements) between prey patches and intensive search (sinuous slow tracks interrupted by numerous stops) within patches (Banks, 1957). Most studies on search behavior have been done in insecticide-free situations (e.g. Ferran \& Dixon, 1993; Ferran et al., 1994). However, coccinellid predators are likely to be exposed to insecticide residues in commercial agricultural ecosystems. Sub-lethal effects of neurotoxic insecticides may affect the behavior, and ultimately the performance, of natural enemies (Haynes, 1988; Croft, 1990). Walking velocity of an insect, the proportion of pesticide transferred from the plant to the insect during walking, and its area of contact with the leaf surface influence mortality levels following exposure to insecticide residues (Jepson et al., 1990). For instance, adult Coccinella septempunctata (L.) walked and groomed significantly more in deltamethrin-treated fields than in unsprayed winter wheat fields (Wiles \& Jepson, 1994).

Imidacloprid (1-[(6-Chloro-3-pyridinyl)methyl]-Nnitro-2-imidazolodinimine), is a chloronicotinyl analogue that acts on postsynaptic acetylcholine receptors in the insect nervous system (Abbink, 1991). Imidacloprid has insecticidal properties on a wide range of arthropods (Elbert et al., 1991; Pflüger \& Schmuck, 1991). Bullock and Pelosi (1993) found that imidacloprid exerted adequate control on 10 selected insect and mite species.
Little is known about the effects of imidacloprid on natural enemies and what is known is conflicting. Pflüger \& Schmuck (1991) stated that because of its predominantly systemic action, imidacloprid has limited effects on natural enemies, including coccinellid predators. Mizell \& Sconyers (1992) assessed the $\mathrm{LD}_{50}$ of several predatory insect species, including last instars and adults of coccinellids such as Hippodamia convergens (GuérinMéneville), and Olla v-nigrum (Uhler). They concluded that, used as foliar sprays, imidacloprid should have detrimental impact on several natural enemy species. Kaakeh et al. (1996) estimated the $\mathrm{LD}_{50}$ of imidacloprid on adult $H$. convergens by topical treatments as $1.8 \mu \mathrm{g} / \mathrm{g}$ and found that $\mathrm{LT}_{50}$ was $5 \mathrm{~h}$, a shorter time than carbaryl $(8 \mathrm{~h})$, chlorpyrifos $(10 \mathrm{~h})$, diazinon $(10 \mathrm{~h})$, propoxur $(10 \mathrm{~h})$ and fipronil $(13 \mathrm{~h})$.

Introduced into France from China in 1982, the polyphagous predator Harmonia axyridis (Pallas)(Coleoptera: Coccinellidae) has been mass-reared on Ephestia kuhniella Zeller (Lepidoptera: Pyralidae) eggs and is now commercially available for the control of the aphids $\mathrm{Mac}$ rosiphum rosae (Ferran et al., 1996) and Phorodon humuli (Trouvé et al., 1996). H. axyridis was also introduced in the United States and is now found throughout North America (Chapin \& Brou, 1991; Tedders \& Schaefer, 1994; Coderre et al., 1995; Nalepa et al., 1996).

There is no published information on sublethal effects of imidacloprid on coccinellid predators. This study reports on the effects of imidacloprid on larvae of $H$. $a x y$ ridis. They were conducted to evaluate the $\mathrm{LD}_{50}$ of imidacloprid on larvae, to determine the effects of contact with imidacloprid-treated plates on larval biology, and to 
evaluate proximate and delayed effects of contact with imidacloprid-treated plates on locomotory behavior of $H$. axyridis larvae.

\section{MATERIALS AND METHODS}

The experiments were conducted with one-day old $H$. axyridis third instars (mean weight $7.2 \pm 1.4 \mathrm{mg}, \mathrm{n}=40$ ) that were reared at $23^{\circ} \mathrm{C}$, a $16 \mathrm{~L}$ : $8 \mathrm{D}$ photoperiod and $70-80 \%$ RH on $E$. kuehniella eggs that were bought from Biotop (Valbonne, France). E. kuehniella eggs were killed either by UV light treatment or by freezing. Although the behavioral effects observed could be somewhat different from those expected with the preferred hosts, i.e. aphids, E. kuehniella eggs allowed standardization of diet quality across experiments. Insecticide solutions were sprayed at a pressure of 0.9 atmosphere for ca. $15 \mathrm{sec}$ on 20 by $20 \mathrm{~cm}$ glass plates in a modified Potter tower (Burgeron, 1956; Brun, 1985, 1988). The sprays, that were uniformly distributed on the glass plates, weighed an average of $0.5 \mathrm{mg} / \mathrm{cm}^{2}$ (0.475-0.625) after drying. Control plates were sprayed with distilled water. Sprayed glass plates were allowed to dry for at least $60 \mathrm{~min}$ before the experiments.

Experiment 1. Effect of imidacloprid applied topically on larval mortality. Larvae were kept at $5^{\circ} \mathrm{C}$ for ca. $20 \mathrm{~min}$. to slow their movements. Each larva was then treated on its dorsum with $5 \mu$ of solution with a Hamilton $(\mathbb{B}$ micro-syringe. The solutions were $0.3,0.15$ (i.e the recommended field rate: ACTA, 1996), 0.015 or $0.0015 \mathrm{~g} / 1$ of imidacloprid (i.e. Confidor ${ }^{\circledR} 200 \mathrm{SL}$, Bayer SA, Puteaux, France) or water (control). There were ca. 20 third instars per treatment and three replicates per treatment. Ten minutes after treatment, larvae were individually reared in petri dishes at $20^{\circ} \mathrm{C}$ a $16 \mathrm{~L}: 8 \mathrm{D}$ photoperiod and $70-80 \%$ RH. In experiments $1,2,3$ and 6 the larvae were reared individually after treatment and provided with $E$. kuehniella eggs ad libitum. Larval mortalities were recorded 24 and $48 \mathrm{~h}$ post-treatment.

Experiment 2. Effect of dose and duration of contact with imidacloprid-treated plates on larval developmental time from third instar to adult. The glass plates were treated with the following solutions: $0.3,0.15,0.015,0.0015 \mathrm{~g} / 1$ of imidacloprid or water (control). Twenty larvae were fed with $E$. kuehniella eggs and maintained at $10^{\circ} \mathrm{C}$ to minimize cannibalism. Larvae were confined for $1,5,25$ or 125 min on imidaclopridtreated plates under a $10-\mathrm{cm}$ plastic petri dish lid, whose inner vertical walls were coated with fluon (a dispersion of polytetrafluorethylene) to prevent larvae from escaping and avoiding contact with the treated glass plate. The upper wall of the petri lid $(6 \mathrm{~cm}$ in diameter) was pierced and covered with a fine mesh material to allow escape of insecticide fumes. The larvae were then transferred with a paintbrush into a petri dish and were reared. Larval mortality and time required to reach the adult stage were recorded daily. Three replicates of the 20 concentration-contact time combinations were conducted.

Experiment 3. Effect of imidacloprid on development as measured by larval weight and developmental time from third instar to the prepupa. Forty larvae were confined for 125 min under a $10 \mathrm{~cm}$ petri dish coated with fluon (as described in Experiment 2) on glass plates treated with: $0.3,0.15,0.015$ or $0.0015 \mathrm{~g} / 1$ of imidacloprid or water (control). They were then reared up to the prepupal stage. Developmental data were recorded daily until maximal weight was reached.

Four developmental parameters were assessed, i.e. (1) average maximum larval weight (mg); (2) day at average maximum larval weight; (3) average weight gain (mg); and (4) average weight gain per day (mg/day) (i.e., from treatment day to maximum larval weight day).

Experiment 4. Direct effects: locomotory behavior of third instars walking on imidacloprid-treated plates. After being starved for $3 \mathrm{~h}, 53$ larvae were confined individually for $1 \mathrm{~min}$ on treated $(0.3 \mathrm{~g} / 1$ imidacloprid) plates under a $2.5 \mathrm{~cm}$ diameter petri dish lid coated with fluon. Control larvae $(n=54$, starved for $3 \mathrm{~h}$ ) were confined $1 \mathrm{~min}$ on water-treated plates, and then locomotory behavior was video recorded. To study the behavioral parameters as a function of time, the $5 \mathrm{~min}$ video recording was divided into 15 successive path lengths of $20 \mathrm{~s}$ each. Behavioral parameters (described subsequently) were then plotted against time.

Experiment 5. Proximate effects: knockdown effect and locomotory behavior of third instars that recovered from contact with imidacloprid-treated plates. Larvae were confined (in groups of ca. 20) with a petri dish lid coated with fluon on glass plates treated with $0.3 \mathrm{~g} / 1$ imidacloprid for $5,30,60,90$ and $120 \mathrm{~min}$. Thirty-nine larvae were placed on control (water) glass plates for $10 \mathrm{~min}$ and 36 larvae on imidacloprid treated plates for each duration of contact. Immediately after treatment, larvae that exhibited a normal posture (i.e., standing) were counted and selected for locomotory studies. The coccinellids were individually placed on untreated glass plates, and confined 1 min under a $2.5 \mathrm{~cm}$ diameter petri lid coated with fluon. By removing the lid, they were allowed to walk freely on a glass plate and video recorded for $5 \mathrm{~min}$.

Experiment 6. Delayed effects $(24 \mathrm{~h})$ : locomotory behavior of imidacloprid-exposed third instars walking on untreated glass plates. Larvae were confined (in groups of ca. 50) for 10 and $60 \mathrm{~min}$ on imidacloprid-treated plates (i.e. $0.3 \mathrm{~g} / 1$ imidacloprid) under a petri dish lid coated with fluon. Control larvae $(\mathrm{n}=$ 50) were confined for $60 \mathrm{~min}$ on water-treated plates. Each group was then reared in plastic containers. Twenty-four hours later, all larvae exhibited a normal posture (i.e., standing) before the experiment. They were starved for $1 \mathrm{~h}$ before the experiment and confined individually on untreated glass plates for $1 \mathrm{~min}$ under a petri dish lid coated with fluon. They were then allowed to walk freely on a glass plate by removing the lid. Locomotory behavior was video recorded.

Behavioral parameters and video recording. For experiments 4,5 , and 6 individual larvae were filmed for up to $5 \mathrm{~min}$ with a video camera (Ferran et al., 1994). Their locomotory behavior was quantified by assessing: (1) duration on the glass plates (seconds); (2) number of stops (per second); (3) linear speed, excluding stops (millimeters per second) and (4) angular speed (degrees per second). Upon video playback, these parameters were assessed and computed with custom software (Ferran et al., 1994).

Statistical analyses. In experiment 1 , Probit analysis was performed with POLO-PC software (LeOra Software, 1994) and the results interpreted according to Robertson \& Preisler (1992). In experiment 2, a two-way analysis of variance of the number of adults obtained by rearing treated larvae was done with STAT ITCF (version 5) (ITCF, 1991). In experiment 3, developmental parameters were tested by a one-way ANOVA (software SuperANOVA; Abacus Concepts, 1991). The behavioral parameters were first calculated with a custom software (Ferran et al. 1994). The results of experiments 4 and 6 were analyzed by ANOVA with STAT ITCF. Because few individuals were available for experiment 5, a Kruskal-Wallis non- parametric test was used with STAT ITCF. 


\section{RESULTS}

Experiment 1. Twenty-four $\mathrm{h}$ after treatment, larval mortality was $0,4.613 .1,53.3$ and $68 \%$ respectively in the treatments with 0 (=control), $0.0015,0.015,0.15$ and $0.3 \mathrm{~g} / 1$ imidacloprid. The same concentrations caused respectively $6.8,4.6,14.7,78.3$ and $73.0 \%$ cumulative mortality after $48 \mathrm{~h}$. The $\mathrm{LD}_{50}$ of imidacloprid applied topically was $0.085 \mathrm{~g} / 1 \quad(95 \%$ confidence interval: $0.049-0.152)$ and $0.082 \mathrm{~g} / 1(95 \%$ confidence interval: $0.039-0.141)$ after 24 and $48 \mathrm{~h}$ respectively. The slopes were $1.103 \pm 0.129$ and $1.517 \pm 0.233$ for 24 and $48 \mathrm{~h}$ respectively: as their calculated t-ratios were respectively 8.5 and $6.5(\mathrm{p}<0.05)$, the regression models were significant.

Experiment 2. There were no significant differences in the number of third instars that became adult among imidacloprid concentrations $(\mathrm{F}=0.70, \mathrm{df}=4, \mathrm{p}=0.067)$ and duration of contact with the plates $(\mathrm{F}=0.62$, $\mathrm{df}=3, \mathrm{p}=$ 0.060 ) (Table 1). The mean number of third instars that became adults ranged from 13.0 to 17.3 in the treated

TABLE 1. Average number of adults and average duration of development (day), obtained after rearing third instar $H$. $a x y$ ridis $(\mathrm{n}=20)$ subjected to different concentrations and contact time on imidacloprid-treated glass plates

\begin{tabular}{ccccc}
\hline $\begin{array}{c}\text { Imidacloprid } \\
\text { concentration } \\
\text { (g/l) }\end{array}$ & \multicolumn{4}{c}{$\begin{array}{c}\text { Duration of contact with imidacloprid-treated } \\
\text { plate (min) }\end{array}$} \\
\cline { 2 - 5 } & 1 & 5 & 25 & 125
\end{tabular}

No. of adults (Mean \pm SEM)

$\begin{array}{lllll}0 \text { (control) } & 14.0 \pm 4.4 & 16.3 \pm 0.6 & 17.0 \pm 2.7 & 15.3 \pm 2.1\end{array}$

$\begin{array}{lllll}0.0015 & 16.7 \pm 2.1 & 17.3 \pm 0.6 & 16.0 \pm 3.6 & 16.0 \pm 4.4\end{array}$

$\begin{array}{lllll}0.015 & 15.0 \pm 1.0 & 14.7 \pm 2.1 & 17.3 \pm 1.2 & 15.7 \pm 2.3\end{array}$

$\begin{array}{lllll}0.15 & 14.7 \pm 1.2 & 17.3 \pm 0.6 & 15.3 \pm 2.5 & 16.7 \pm 0.6\end{array}$

$\begin{array}{lllll}0.3 & 16.3 \pm 1.5 & 14.7 \pm 4.5 & 15.7 \pm 0.6 & 13.0 \pm 2.0\end{array}$

Duration of development (day)(Mean \pm SEM)

$\begin{array}{lllll}0 \text { (control) } & 14.7 \pm 1.0 & 14.8 \pm 0.9 & 13.9 \pm 0.9 & 14.8 \pm 1.8\end{array}$

$\begin{array}{lllll}0.0015 & 14.6 \pm 1.3 & 14.3 \pm 1.1 & 14.6 \pm 1.3 & 14.9 \pm 1.4\end{array}$

$\begin{array}{lllll}0.015 & 15.2 \pm 1.5 & 14.8 \pm 1.2 & 15.0 \pm 1.2 & 14.6 \pm 1.0\end{array}$

$\begin{array}{lllll}0.15 & 14.6 \pm 1.4 & 14.2 \pm 0.9 & 14.5 \pm 1.0 & 14.4 \pm 1.0\end{array}$

\begin{tabular}{llllll}
0.3 & $14.9 \pm 1.3$ & $14.8 \pm 1.4$ & $14.8 \pm 1.7$ & $15.3 \pm 1.6$ \\
\hline
\end{tabular}

group, and from 14.0 to 17.0 in the control group, regardless of the duration of contact. The average duration (in days) of development from 3 rd instar to the adult stage was not significantly different between different durations of contact ( $F=1.08, \mathrm{df}=3, \mathrm{p}=\mathbf{0 . 3 6}$ ) (Table 1), but was significantly different between imidacloprid concentrations $(\mathrm{F}=3.43$, $\mathrm{df}=4, \mathrm{p}=0.01$ ). The calculated averages ranged from 14.4 to 14.9 days, but the latter significance level may be biologically irrelevant because the measurements were made daily.

Contact with imidacloprid-treated plates did not affect the mortality and duration of larval development. However, we observed a temporary knockdown effect (i.e., larvae immobile, lying on their side), typical for higher concentrations and duration of contact with imidaclopridtreated plates.

Experiment 3. There were no significant differences among maximal weight $(\mathrm{F}=1.23, \mathrm{df}=4, \mathrm{p}=0.30)$ and average weight gain $(F=1.20, \mathrm{df}=4, \mathrm{p}=0.31)$ in treated larvae (Table 2). No significant differences in the day of maximal weight were detected by the ANOVA ( $F=1.49$, $\mathrm{df}=4, \mathrm{p}=0.21$ ) among imidacloprid concentrations. The

TABLE 2. Growth of $H$. axyridis third instars subjected to a 125 -min contact with imidacloprid-treated glass plate $(n=40)$

\begin{tabular}{|c|c|c|c|c|}
\hline \multirow[b]{2}{*}{$\begin{array}{c}\text { Imidacloprid } \\
\text { concentration } \\
(\mathrm{g} / \mathrm{l})\end{array}$} & \multicolumn{4}{|c|}{ Mean \pm SEM } \\
\hline & $\begin{array}{l}\text { Maximum } \\
\text { larval } \\
\text { weight } \\
(\mathrm{mg})\end{array}$ & $\begin{array}{l}\text { Weight } \\
\text { gain (mg) }\end{array}$ & $\begin{array}{c}\text { Day at } \\
\text { maximum } \\
\text { larval } \\
\text { weight }\end{array}$ & $\begin{array}{c}\text { Weight } \\
\text { gain per } \\
\text { day }^{\mathrm{a}} \\
(\mathrm{mg} / \text { day })\end{array}$ \\
\hline 0 (control) & $34.9 \pm 1.3$ & $27.7 \pm 1.2$ & $4.0 \pm 0.2$ & $7.1 \pm 0.4$ \\
\hline 0.0015 & $34.2 \pm 1.6$ & $26.4 \pm 1.6$ & $4.1 \pm 0.3$ & $6.3 \pm 0.5$ \\
\hline 0.015 & $32.1 \pm 1.8$ & $24.5 \pm 1.8$ & $4.3 \pm 0.3$ & $5.3 \pm 0.4$ \\
\hline 0.15 & $36.1 \pm 1.4$ & $28.4 \pm 1.3$ & $4.5 \pm 0.2$ & $6.3 \pm 0.4$ \\
\hline 0.3 & $32.4 \pm 1.5$ & $25.2 \pm 1.4$ & $4.7 \pm 0.2$ & $5.5 \pm 0.3$ \\
\hline
\end{tabular}

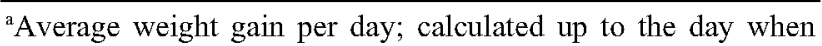
maximum larval weight was recorded.

day at which maximum larval weight was reached was earlier in the control (d 4.0), and increased consistently with imidacloprid concentration, reaching the highest value ( $\mathrm{d} 4.7$ ) for imidacloprid concentration $0.3 \mathrm{~g} / \mathrm{l}$. Again, there were significant differences among average weight gain per day ( $\mathrm{F}=2.86$, df $=4, p=0.03$ ), the highest value being maximal for the control group (7.1 $\mathrm{mg} /$ day) and minimal (5.5 $\mathrm{mg} /$ day) for the $0.3 \mathrm{~g} / 1$ imidacloprid treatment. Among individuals treated with imidacloprid, the difference between the maximum (6.3) and minimum (5.3) weight gain per day was equal to the periodicity of weight measurement, i.e. 1 day. Compared to untreated individuals, imidacloprid slightly affects weight gain per day in treated individuals.

Experiment 4. The larvae stayed significantly longer on treated $(59.8 \mathrm{~s})$ than on control $(37.7 \mathrm{~s})$ plates (Table 3). The longer stay on treated plates could be explained by the significantly greater number of stops (1.6 more stops per second), significantly lower linear speed $(0.3 \mathrm{~mm}$ per second), and significant greater angular speed (12.4 degrees per second faster).

For all path lengths, the total stay on the glass plates was consistently lower for treated than untreated larvae (Fig. 1A). Considering the number of stops, linear speed and angular speed, three periods could be distinguished (Figs 1B, C, D): period 1 (i.e., successive path lengths 1 to 6), where treated larvae generally showed a higher number of stops, a higher angular speed and a lower linear speed than untreated larvae (i.e., a search pattern more akin to intensive searchs in treated than untreated individuals); period 2 (i.e., successive path lengths 7 to 10) where angular speed, number of stops and linear speed were approximately equal in treated and untreated groups (i.e., a search pattern more akin to extensive 
TABLE 3. Locomotory behavior of $H$. axyridis third instar larvae walking on imidacloprid-treated $(0.3 \mathrm{~g} / 1)$ plates

\begin{tabular}{lccc}
\hline $\begin{array}{l}\text { Behavioral parameter } \\
(\text { mean } \pm \text { SEM })\end{array}$ & $\begin{array}{c}\text { Control } \\
(\mathrm{n}=54)\end{array}$ & $\begin{array}{c}\text { Imidacloprid } \\
\text {-treated plate } \\
(\mathrm{n}=53)\end{array}$ & $\mathrm{F}^{\mathrm{a}}(\mathrm{p})^{\mathrm{b}}$ \\
\hline $\begin{array}{l}\text { Stay on glass plate } \\
(\mathrm{sec})\end{array}$ & $37.7 \pm 11.2$ & $59.8 \pm 14.2$ & $2.39(0.002)$ \\
$\begin{array}{l}\text { Number of stops } \\
\text { (per sec) }\end{array}$ & $6.2 \pm 0.7$ & $7.8 \pm 0.7$ & $3.13(0.002)$ \\
$\begin{array}{l}\text { Linear speed, excluding } \\
\text { stops (mm per sec) }\end{array}$ & $9.8 \pm 0.2$ & $9.5 \pm 0.1$ & $3.10(0.003)$ \\
$\begin{array}{l}\text { Angular speed } \\
\text { (degrees per sec) }\end{array}$ & $48.7 \pm 4.9$ & $61.4 \pm 5.3$ & $3.48(0.009)$ \\
\hline${ }^{\mathrm{a}}$ value of the computed statistic F, from Anova. & \\
${ }^{\mathrm{b}}$ probability associated with calculated F & &
\end{tabular}

searchs in treated individuals); and period 3 (i.e., successive path lengths 11 to 15 ) where the behavior was the same as described in period 1.

Experiment 5. Preliminary observations (not quantified) in experiment 2 of temporary knockdown effects at higher imidacloprid concentration and stay on plates were confirmed in experiment 5 at a concentration of $0.3 \mathrm{~g} / 1$ imidacloprid. There were 33.3, 58.3, 86.1, 97.2 and $88.9 \%$ ( $n=36$ individuals per duration) of larvae knocked down respectively after exposure for 5, 30, 60, 90 and $120 \mathrm{~min}$ to imidacloprid-treated plates and $10.8 \%(\mathrm{n}=39$ larvae) in the control.

As the percentages of larvae knocked down were high (i.e. $>86 \%$ ) in treatments $\geq 60 \mathrm{~min}$, experiments on locomotory behavior were performed only with larvae from the control, and from shorter treatments. Among the treatments there were significant differences in the duration of stay on plates, the number of stops, and the angular speed (Table 4). For the stay on plates, number of stops, and angular speed, the differences were markedly higher in the 30-min treatment than in the control and the 5-min treatment. There were no significant differences in linear speed among treatments. For the 30 min treatment, larvae stayed longer on treated plates because of an increase in number of stops and an increase in angular speed.

Experiment 6. Locomotory behavior of larvae was affected as observed in experiment 5 , even $24 \mathrm{~h}$ after contact with imidacloprid-treated plates (Table 5). Compared with control larvae, duration of stay on untreated plates was significantly higher in larvae treated for both 10 and $60 \mathrm{~min}$. This greater duration resulted from a significant increase in the number of stops, a significant increase in angular speed and a significant decrease in linear speed. All behavioral parameters had similar values for larvae exposed to treated plates for 10 and $60 \mathrm{~min}$.

\section{DISCUSSION}

In integrated pest management programs, $H$. axyridis will likely be exposed to insecticide residues on crops. In field situations, exposure of coccinellid predators to pesticides, including imidacloprid, may occur as a result of ingestion of treated prey, direct exposure to sprays or by contact with treated surfaces. Our study focused on the latter two mechanisms, with particular reference to larval biology and locomotory behavior.

Imidacloprid had a lethal effect when applied topically (Experiment 1), as found for $H$. convergens adults by Kaakeh et al. (1996). Contact with imidacloprid-treated plates did not affect larval mortality (Experiment 2), or larval growth (Experiment 3). However, there were significant differences in average weight gain per day (Experiment 3). Because there is a linear relationship between the number of aphids consumed and larval weight (Ferran \& Larroque, 1977), larval weight parameters sug gest that the predatory capacity of larvae will be unaffected by contact with imidacloprid-treated surfaces. However, larvae that contacted imidacloprid residues showed a knockdown effect (Experiment 5). Knockdown effects, also observed in other coccinellid predators, e.g.
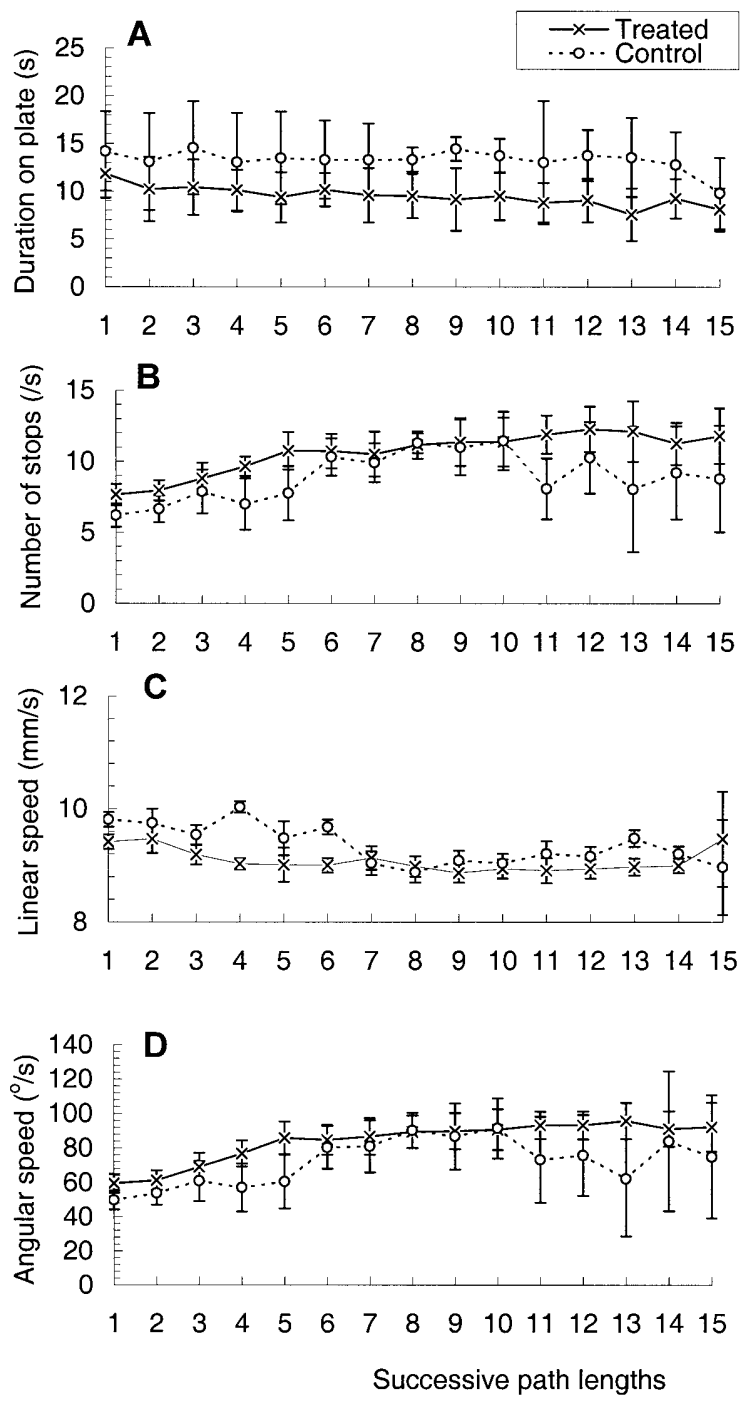

Fig. 1. Locomotory behavior of $H$. axyridis third instars walking on untreated (control) and imidacloprid-treated glass plates. The 5 min video recording was divided into 15 successive path lenghts of 20 seconds each. Vertical bars are standard error of means. 
TABLE 4. Locomotory behavior of Harmonia axyridis third intars walking on untreated glass plates. Only individuals that recovered after 5 and $30 \mathrm{~min}$ contact with an imidaclopridtreated $(0.3 \mathrm{~g} / 1)$ plate.

\begin{tabular}{|c|c|c|c|c|}
\hline \multirow{2}{*}{$\begin{array}{c}\text { Behavioral } \\
\text { parameter } \\
\text { (mean } \pm \text { SEM) }\end{array}$} & \multirow[b]{2}{*}{$\begin{array}{l}\text { Control } \\
(\mathrm{n}=35)\end{array}$} & \multicolumn{2}{|c|}{ Imidacloprid-treated plate } & \\
\hline & & $\begin{array}{c}5 \min \\
(\mathrm{n}=24)\end{array}$ & $\begin{array}{c}30 \min \\
(\mathrm{n}=15)\end{array}$ & $\mathrm{H}^{\mathrm{a}}(\mathrm{p})^{\mathrm{b}}$ \\
\hline
\end{tabular}

\begin{tabular}{|c|c|c|c|c|}
\hline $\begin{array}{l}\text { Stay on } \\
\text { glass plate (sec) }\end{array}$ & $43.6 \pm 6.6$ & $42.6 \pm 7.6$ & $63.3 \pm 9.9$ & $9.52(0.01)$ \\
\hline $\begin{array}{l}\text { Number of } \\
\text { stops (per sec) }\end{array}$ & $9.5 \pm 0.7$ & $9.0 \pm 0.9$ & $11.5 \pm 1.7$ & $6.03(0.005)$ \\
\hline $\begin{array}{l}\text { Linear speed, } \\
\text { excluding stops } \\
\text { (mm per sec) }\end{array}$ & $9.4 \pm 0.2$ & $9.4 \pm 0.3$ & $9.1 \pm 0.2$ & $1.58(0.46)$ \\
\hline $\begin{array}{l}\text { Angular speed } \\
\text { (degrees per sec) }\end{array}$ & $80.8 \pm 7$ & $85.8 \pm 10.5$ & $114.8 \pm 5.0$ & $22.7(0.001)$ \\
\hline
\end{tabular}

Coleomegilla maculata Timberlake (Roger et al., 1994, 1995), may affect predatory performance.

Contact with imidacloprid caused effects on the locomotory behavior of $H$. axyridis larvae (Experiments 4, 5 and 6). Compared with the control larvae, imidacloprid caused an increase in the number of stops (per second) and in angular speed (degrees per second). Consequently, larvae stayed longer on the treated plates. The changes in locomotory behavior occurred rapidly (Experiment 5), and probably preceeded the knockdown effect. Although larvae apparently rapidly recovered from the knockdown state, changes in locomotory behavior persisted for at least $24 \mathrm{~h}$ after contact with imidacloprid-treated plates (Experiment 6).

In an integrated pest management context, imidacloprid could be detrimental to $H$. axyridis predatory activities in three ways. First, larvae could be killed by direct sprays of imidacloprid on plants. Second, contact with imidacloprid residues may cause the larvae to fall off the plant, by knockdown effect. Although the fate of fallen larvae is unknown, the probability of mortality could be enhanced due to adverse conditions (e.g., remoteness of optimal

TABLE 5. Delayed effect (24 h) of contact with imidaclopridtreated $(0.3 \mathrm{~g} / 1)$ glass plates on $H$. axyridis larval locomotory behavior.

\begin{tabular}{|c|c|c|c|c|}
\hline \multirow[b]{2}{*}{$\begin{array}{c}\text { Behavioral } \\
\text { parameter } \\
\text { (mean } \pm \text { SEM) }\end{array}$} & \multirow[b]{2}{*}{$\begin{array}{l}\text { Control } \\
(\mathrm{n}=50)\end{array}$} & \multicolumn{2}{|c|}{ Imidacloprid-treated plate } & \multirow[b]{2}{*}{$F^{a}(p)^{b}$} \\
\hline & & $\begin{array}{c}10 \min \\
(n=46)\end{array}$ & $\begin{array}{c}60 \mathrm{~min} \\
(\mathrm{n}=44)\end{array}$ & \\
\hline $\begin{array}{l}\text { Stay on } \\
\text { untreated } \\
\text { plate (sec) }\end{array}$ & $71.3 \pm 76.0$ & $109.4 \pm 75.6$ & $103.9 \pm 80.8$ & $4.51(0.012)$ \\
\hline $\begin{array}{l}\text { Number of } \\
\text { stops (per sec) }\end{array}$ & $5.4 \pm 2.2$ & $6.9 \pm 1.4$ & $6.6 \pm 1.6$ & $13.6(0.000)$ \\
\hline $\begin{array}{l}\text { Linear speed, } \\
\text { excluding } \\
\text { stops }(\mathrm{mm} / \mathrm{sec})\end{array}$ & $9.9 \pm 1.4$ & $9.3 \pm 0.5$ & $9.3 \pm 0.5$ & $7.9(0.000)$ \\
\hline $\begin{array}{l}\text { Angular speed } \\
\text { (degrees per } \\
\text { sec) }\end{array}$ & $56.0 \pm 25.2$ & $75.0 \pm 22.1$ & $73.7 \pm 24.4$ & $12.5(0.000)$ \\
\hline
\end{tabular}

prey patches, soil predators, energy requirements to climb back on the plant). Third, locomotory behavior changes due to contact with imidacloprid residues for more than 5 min would increase the duration of contact with the treated plant and the probability of knockdown effect. In the context of agroecosystems, it is possible that imidacloprid also exerts negative effects over a wide range of natural enemies and additional research is needed.

ACKNOWLEDGEMENTS. This work was financed by an Organization for Economic Co-operation and Development (OECD) Postdoctoral Fellowship awarded to C. Vincent under the program "Bi ological Resource Management for Sustainable Agriculture Systems (1995-1999)", a special grant awarded to A. Ferran by "Services des Relations Internationales" of Institut National de la Recherche Agronomique (INRA), France, and an Agriculture and Agri-Food Canada/INRA exchange program grant. We thank Stéphan Giroux for data analysis of some experiments. Noubar J. Bostanian and Stéphan Giroux commented an early version of the manuscript. This is contribution No. 335/2000.07.02R of Agriculture and Agri-Food Canada Research Horticultural Research and Development Centre at Saint-Jean-sur-Richelieu.

\section{REFERENCES}

ABACus CONCEPTS 1991: SuperANOVA, The Accessible General Linear Modeling Package (v1.11 for the Macintosh Computer), Berkeley, California.

AвBInk J. 1991: The biochemistry of imidacloprid. PflSchutzNachr. Bayer 44: 183-195.

ACTA 1996: Index phytosanitaire 1996. Association de Coordination Technique Agricole (ACTA), Paris, 576 p.

BANKS C.J. 1957. The behaviour of individual coccinellid larvae on plants. Br. J. Anim. Behav. 5: 12-24.

BRUN J. 1985: Coccinella septempunctata L. (Coccinellidae, Coleoptera). In Hassan S.A. (ed.): Standard Methods to Test the Side-Effects of Pesticides on Natural Enemies of Insects and Mites Developed by the IOBC/WPRS Working Group "Pesticides and Beneficial Organisms". EPPO Bulletin 15: 214-255.

BRUN J. 1988: Méthode de laboratoire pour étudier les effets secondaires des pesticides sur la coccinelle Semiadalia 11 notata Schn. IOBC, WPRS Bulletin 11: 85-90.

Bullock R.C. \& Pelosi R.R. 1993: Toxicity of imidacloprid to selected arthropods in the citrus greenhouse and grove. Proc. Fla St. Hort. Soc. 106: 42-47.

BURGERON A. 1956: Pulvérisation et poudrage au laboratoire par des préparations pathogènes insecticides. Ann. Epiphyties 7: 677-686.

Chapin J.B. \& Brou V.A. 1991: Harmonia axyridis (Pallas), the third species of the genus to be found in the United States (Coleoptera: Coccinellidae). Proc. Entomol. Soc. Wash. 93: 630-635.

Coderre D., Lucas E. \& Gagné I. 1995: The occurrence of Harmonia axyridis (Pallas) (Coleoptera: Coccinellidae) in Canada. Can. Entomol. 127: 609-611.

Croft B.A. 1990: Arthropod Biological Control Agents and Pesticides. John Wiley \& Sons, New York, 723 pp.

Elbert A., Becker B., Hartwig J. \& Erdelen C. 1991: Imidacloprid - a new systemic insecticide. PflSchutz Nachr. Bayer 44: 113-136.

Ferran A. \& Dixon A.G. 1993: Foraging behavior of ladybird larvae (Coleoptera: Coccinellidae). Eur. J. Entomol. 90: $383-402$. 
Ferran A. \& Larroque M.M. 1977: Etude des relations hôtesprédateurs: la consommation et l'utilisation d'un puceron, Myzus persicae Sulz. par les différents stades larvaires de la coccinelle Semiadalia undecimnotata Schn. (Col. Coccinellidae). Ann. Zool. Ecol. Anim. 9: 665-690.

Ferran A., Ettifouri M., Clement P. \& Bell W.J. 1994: Sources of variability in the transition from extensive to intensive search in coccinellid predators (Homoptera: Coccinellidae). J. Insect Behav. 7: 633-647.

Ferran A., Niknam H., Kabiri F., Picart J.-L., De Herce C., Brun J., IPERTI G. \& LAPCHIN L. 1996: The use of Harmonia axyridis larvae (Coleoptera: Coccinellidae) against Macrosiphum rosae (Hemiptera: Sternorrhyncha: Aphididae) on rose bushes. Eur. J. Entomol. 93: 59-67.

HAYNES K.F. 1988: Sublethal effects of neurotoxic insecticides on insect behavior. Annu. Rev. Entomol. 33: 149-168.

ITCF 1991: STAT ITCF (Institut Technique des Céréales et Fourrages) (version 5 for IBM compatible computers), Boigneville, France.

Jepson P.C., Chaudhry A.G., Salt D.W., Ford M.G., EFe E. \& Chowdrhury A.B.M.N.U. 1990: A reductionist approach towards short-term hazard analysis for terrestrial invertebrates exposed to pesticides. Funct. Ecol. 4: 339-347.

KaAkeH N., KaAKeH W. \& BenNett G.W. 1996: Topical toxicity of imidacloprid, fipronil, and seven conventional insecticides to the adult convergent lady beetle (Coleoptera: Coccinellidae). J. Entomol. Sci. 31: 315-322.

LeOra Software. 1994: Polo-PC, Probit and Logit Analysis User's guide. LeOra Software, Berkeley, CA, 28 pp.
Mizell R.F. \& SCONYERS M.C. 1992: Toxicity of imidacloprid to selected arthropod predators in the laboratory. Fla Entomol 75: 277-280.

Nalepa C.A., KidD K.A. \& Ahlstrom K.R. 1996: Biology of Harmonia axyridis (Coleoptera: Coccinellidae) in winter aggregations. Ann. Entomol. Soc. Am. 89: 681-685.

Pflưger W. \& Schmuck R. 1991: Ecotoxicological profile of imidacloprid. PflSchutz Nachr. Bayer 44: 145-158.

Robertson J.L. \& Preisler H. 1992: Pesticide Bioassays with Arthropods. CRC Press, Boca Raton, Fla., 127 pp.

Roger C., Coderre D. \& Vincent C. 1994: Mortality and predation efficiency of Coleomegilla maculata lengi Timb. (Col., Coccinellidae) following pesticide applications. J. Econ. Entomol. 87: 583-588.

Roger C., Vincent C. \& Coderre D. 1995: Mortality and predation efficiency of Coleomegilla maculata lengi Timb. (Col., Coccinellidae) following application of Neem extracts (Azadirachta indica A. Juss., Meliaceae). J. Appl. Entomol. 119: 439-443.

TEDders W.L. \& Schaefer P.W. 1994: Release and establishment of Harmonia axyridis (Coleoptera: Coccinellidae) in the southeastern United States. Entomol. News 105: 228-243.

Trouvé C., Lédée S., Brun J. \& FerRan A. 1996: Lutte biologique contre le puceron du houblon. - Bilan de trois années d'étude dans le Nord de la France. Phytoma-La Défense Végétaux 486: 41-44.

Wiles J.A. \& JEPSON P.C. 1994: Sub-lethal effects of deltamethrin residues on the within-crop behaviour and distribution of Coccinella septempunctata. Entomol. Exp. Appl. 72: $33-45$.

Received January 24, 2000; accepted August 4, 2000 